\title{
Panorama Treinamento e Desenvolvimento do Hospital Regional de Cotia VS Brasil
} Hospital Regional
de Cotia $\overline{\text { seconcisp/OSS }}$

HRC
Autores: COSTA, Roberta da Silva; FARIAS, Marinalda Maria da Costa.

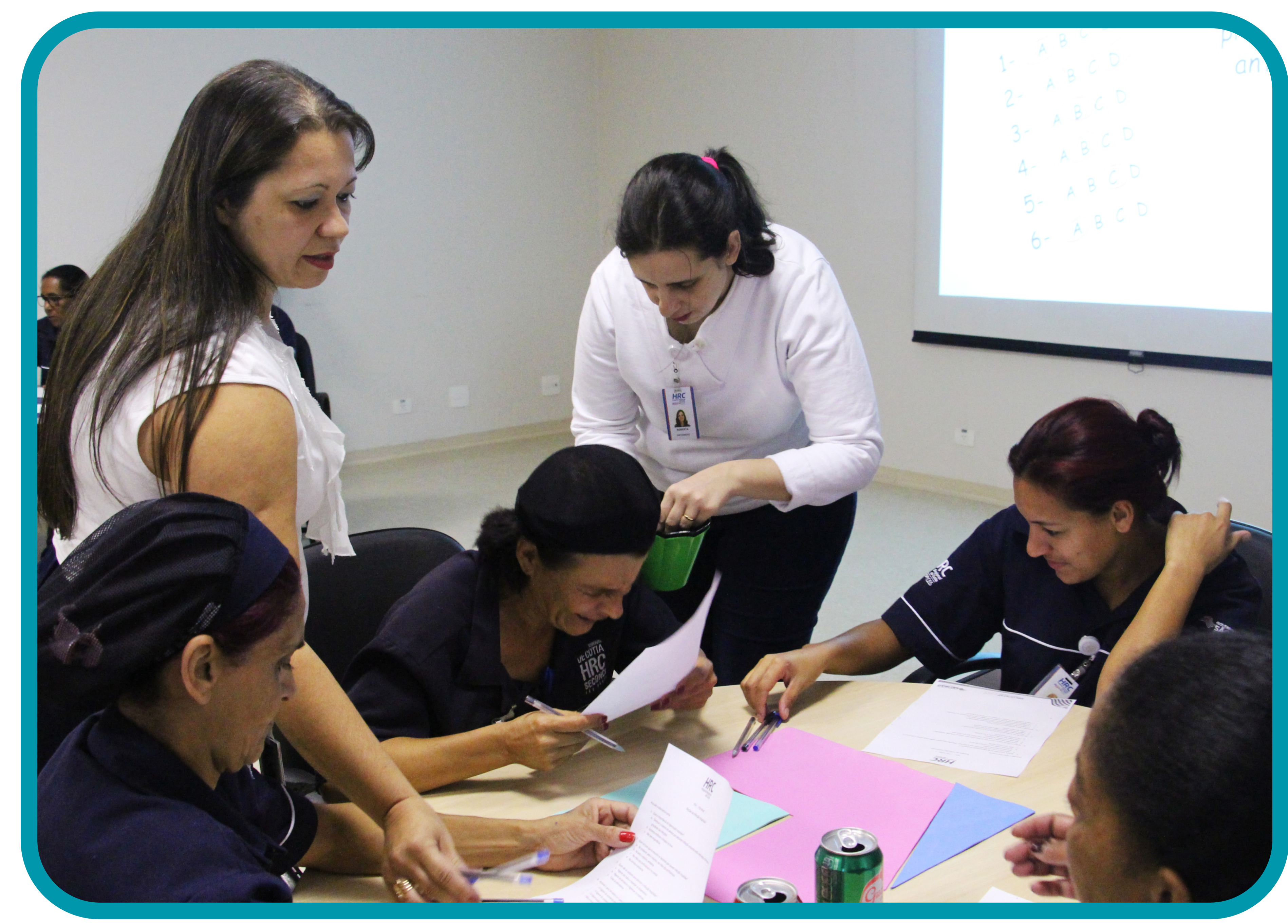

de horas de treinamento anual no Brasil 18 horas, percentual de treinamento de gestores e não gestores $48 \%$ e $52 \%$ respectivamente. O valor total de investimentos no ano de 2018, no HRC, foi de R\$ 857.750,38 para aproximadamente 650 colaboradores CLT. O valor investido por colaborador foi de R\$1319,62. Quando compramos esses números, observa-se que o Brasil apresenta: investimento anual de R\$ 602.000,00 para um total de 501 a 1000 colaboradores, e um valor médio de investimento por colaborador de R\$746,00.

\section{Conclusão}

Por mais moderna e tecnológica que uma empresa possa ser ou parecer, ela precisa de equipes preparadas, motivadas e engajadas, se quiser prestar uma assistência segura. Apesar da crise política e econômica do país, o HRC, conhecendo suas necessidades e planejando de forma antecipada e sustentável os treinamentos, conseguiu garantir o investimento contínuo na qualificação de seus colaboradores a fim de garantir uma assistência segura e de qualidade. 